\title{
Part I. Development of a Model System for Studying Nitric Oxide in Tumors: High Nitric Oxide-Adapted Head and Neck Squamous Cell Carcinoma Cell Lines
}

Yaroslav Yarmolyuk, ${ }^{a}$ Benjamin J. Vesper, ${ }^{\mathrm{a}, \mathrm{b}}$ William A. Paradise, ${ }^{\mathrm{a}, \mathrm{b}}$ Kim M. Elseth, ${ }^{\mathrm{a}, \mathrm{b}}$ Gabor Tarjan, ${ }^{\mathrm{c}}$ G. Kenneth Haines III, ${ }^{\mathrm{d}}$ James A. Radosevich, ${ }^{\mathrm{a}, \mathrm{b}}$

${ }^{\mathrm{a}}$ Center for Molecular Biology of Oral Diseases, College of Dentistry, University of

Illinois at Chicago, Chicago, IL, 60612, USA

${ }^{\mathrm{b}}$ Jesse Brown VAMC, Chicago, IL, 60612, USA

${ }^{c}$ Department of Pathology, John H. Stroger, Jr. Hospital of Cook County, Chicago, IL, 60612, USA

${ }^{\mathrm{d}}$ Department of Pathology, Yale University School of Medicine; New Haven, CT, 06510, USA

*Corresponding author: James A. Radosevich, Ph.D.; Center for Molecular Biology of Oral Diseases, University of Illinois at Chicago, College of Dentistry; 801 S. Paulina St., Chicago, IL, 60612, USA; phone: (312) 996-9538, fax: (312) 996-9592, e-mail address: jrados@uic.edu

Running title: Nitric Oxide-Adapted HNSCC Cell Lines 


\begin{abstract}
The free radical nitric oxide (NO) is over-expressed in many tumors, including head and neck squamous cell carcinomas (HNSCC). However, the role NO plays in tumor pathophysiology is still not well understood. We herein report the development of an in vitro model system which can be used to probe the role of NO in the carcinogenesis of HNSCC. Five HNSCC cell lines were adapted to a high NO (HNO) environment by gradually introducing increasing concentrations of DETA-NONOate, a nitrogen-based NO donor, to cell media. The adaptation process was carried out until a sufficiently high enough donor concentration was reached which enabled the HNO cells to survive and grow, but which was lethal to the original, unadapted ("parent") cells. The adapted HNO cells exhibited analogous morphology to the parent cells, but grew better than their corresponding parent cells in normal media, on soft agar, and in the presence of hydrogen peroxide, an oxygen-based free radical donor. These results indicate the HNO cell lines are unique and possess biologically different properties than the parent cell lines from which they originated. The $\mathrm{HNO} /$ parent cell lines developed herein may be used as a model system to better understand the role NO plays in HNSCC carcinogenesis.
\end{abstract}

\title{
Keywords
}

Nitric oxide, nitrogen reactive species, squamous cell carcinoma, oral cancer, nitric oxide synthase (NOS), free radical exposure, head and neck cancer 


\section{Introduction}

According to American Cancer Society estimates, the United States reported 48,010 new cases of head and neck cancer in 2009, and an estimated 11,260 deaths from this disease. Tumors arising from the larynx, tongue, mouth, and pharynx account for over $96 \%$ of these cases [1], and greater than $90 \%$ of these cancers are squamous cell carcinomas [2].

Cigarette smoking - the leading risk factor in head and neck cancers — has been shown to produce free radicals such as reactive oxygen species and nitrogen-based free radicals, including nitric oxide (NO) [3-5]. These molecules may play an important role in tumor development and propagation, as increased concentrations of these free radicals can cause DNA damage such as point mutations and chromosomal breakage. This DNA damage results in mutations to proto-oncogenes and tumor-suppressor genes, ultimately leading to malignant transformation and cancer development [6-8].

NO is a nitrogen-based free radical that is synthesized by a family of enzymes known as nitric oxide synthase (NOS). It plays an essential role in many normal physiological processes such as vasodilation, central and peripheral neurotransmission, hormone secretion, inhibition of platelet aggregation, and mediation of immune response. It has also been implicated in a number of pathophysiological processes such as inflammation, septic shock, hypertension, atherosclerosis, and carcinogenesis [9-11].

While NO is known to be present in normal tissue, and necessary for proper cellular function, its role in tumor development and progression is less clear [12]. Increased serum levels of NO and/or increased expression of NOS has been found in a variety of tumors from different sites [13-18], including head and neck squamous cell 
carcinomas (HNSCC) [19-22]. Further studies have suggested chronic overproduction of NO leads to a variety of pathologic disorders, including carcinogenesis [23-25].

Despite the recent advancements in understanding the role of NO in cancer, several clinically relevant questions still remain unanswered. For example, it is still unknown how the NO microenvironment of a tumor affects its progression, and how NO expression is influenced by the treatment of tumors. Similarly, further research needs to be conducted to determine if the expression levels of NO should dictate the use of a particular therapeutic approach. Given the difficulty in attempting to answer these questions directly in humans, it would be extremely valuable if an in vitro cell line model system could be established that mimicked the varying degrees of nitrosative stress observed in clinically presenting tumors. Such a system would allow a spectrum of NO expression to be studied - from very low to very high levels of expression - in order to better understand the role NO plays in tumor progression.

To this end, we have recently developed such a cell line system in human and mouse lung adenocarcinoma cell lines [26], as well as in human breast adenocarcinoma cell lines [27]. Over the period of several months, these tumor cells were adapted to increasing concentrations of a nitric oxide donor, ultimately reaching extremely high nitric oxide (HNO) levels. The HNO-adapted cells were able to grow and eventually thrive in a comparatively harsh free radical environment—an environment which was found to be lethal to the original, unadapted ("parent") cell lines. Herein we extend the universality of the cell line model to study five HNSCC cell lines. 


\section{Materials and Methodology}

\section{Cell Culture and Cell Lines}

All media and supplements were purchased from Invitrogen Corporation (Carlsbad, CA, USA) except where noted. Five human head and neck squamous cell carcinoma (HNSCC) cell lines (three originating from the tongue: SCC016, SCC040, SCC056; one from the floor of mouth: SCC114; and one from the alveolar ridge: SCC116) [28] were grown in MEM media. Cell lines were generously obtained from Dr. Susanne Gollin (University of Pittsburgh Cancer Institute, Pittsburgh, PA, USA). All media was supplemented with $10 \%$ fetal calf serum (FCS) inactivated at $56^{\circ} \mathrm{C}$ for 30 minutes, $100 \mathrm{U} / \mathrm{mL}$ penicillin, $100 \mu \mathrm{g} / \mathrm{mL}$ streptomycin, $2 \mathrm{mM} \mathrm{L-glutamine,} \mathrm{and} 2.5$ $\mu \mathrm{g} / \mathrm{mL}$ Amphotericin B solution. The MEM media was additionally supplemented with $100 \mathrm{mM}$ MEM nonessential amino acids and $1 \mathrm{mM}$ sodium pyruvate (Mediatech, Inc., Manassas, VA, USA). Cell lines were grown in a humidified incubator at $37^{\circ} \mathrm{C}$ and $5 \%$ $\mathrm{CO}_{2}$.

The nitric oxide donor (Z)-1-[2-(2-aminoethyl)-N-(2ammonioethyl)amino]diazen-1-ium-1,2-diolate (DETA-NONOate) (Sigma-Aldrich Corp., St. Louis, MO, USA) was utilized in this study. DETA-NONOate stock solutions were prepared in sterilized water and sterile filtered $(0.22 \mu \mathrm{m})$. Solutions were aliquoted and stored at $-20{ }^{\circ} \mathrm{C}$ until ready for use.

\section{Determination of Adaptation End-Point}

Before the adaptation process was initiated (discussed in the next section), the concentration of NO which was lethal to the cells was determined. Cells from each of the 
five cell lines were seeded $(100 \mu \mathrm{L})$ into 96-well microtiter plates and grown for 24 hours, to $\sim 70 \%$ confluency. The media was then removed, and the cells were treated with $100 \mu \mathrm{L}$ media containing varying concentrations $(0-600 \mu \mathrm{M})$ of DETA-NONOate. Following an additional 72 hour incubation period, cell proliferation/viability was assessed using the 3-(4,5-dimethylthiazol-2-yl)-2,5-diphenyltetrazolium bromide (MTT) assay. Media was removed from each well, and $100 \mu \mathrm{L}$ of $2 \mathrm{mg} / \mathrm{mL}$ MTT (SigmaAldrich Corp., St. Louis, MO, USA) in phosphate buffer saline (PBS) was added. Plates were then placed in an incubator $\left(37^{\circ} \mathrm{C}\right)$ for 5 hours, during which time purple formazan crystals formed upon the reaction of the MTT with mitochondrial dehydrogenases of viable cells. Following the incubation period, the MTT solution was removed, and 100 $\mu \mathrm{L}$ of Dimethyl Sulfoxide (DMSO) was added. The absorbance of the resulting purple solution in each well was read $(540 \mathrm{~nm})$ using a SpectraMax ${ }^{\circledR}$ Plus 384 spectrophotometer (Molecular Devices, Inc., Sunnyvale, CA, USA). Each experiment was independently conducted a minimum of three times, and a minimum of four replicate wells were tested for each cell line at each concentration. Data was normalized to the mean optical density of the untreated control cells.

\section{Cell Adaptation Process}

The five HNSCC cell lines were "adapted" to the nitric oxide donor DETANONOate. The adaptation process was initiated by passaging cells with trypsin-EDTA and transferring the cells to a new flask containing media supplemented with $50 \mu \mathrm{M}$ DETA-NONOate. The DETA-NONOate solution was prepared immediately prior to the addition of cells into the growth media. Cells were then incubated at $37{ }^{\circ} \mathrm{C}$ and $5 \% \mathrm{CO}_{2}$ 
until they reached $\sim 90 \%$ confluency. At this time, the cells were again passaged, and the resulting cultures were grown in media treated with $75 \mu \mathrm{M}$ DETA-NONOate. The NO donor concentration was increased at $25 \mu \mathrm{M}$ increments in this fashion until a final concentration of $600 \mu \mathrm{M}$ DETA-NONOate was reached. Aliquots of the adapted cells were periodically removed for cryostorage during the adaptation process.

In addition to the adapted cells, separate "parent" cells were maintained as controls. No nitric oxide donor was added to the parent cells, and these cells were grown under standard conditions.

The cells were replenished with media containing DETA-NONOate every 2-3 days, both during the adaptation process and the subsequent maintenance of the fully adapted cells. Media was also replenished every 2-3 days for the parent cells.

Cells were imaged at 100x magnification using an InfinityX-32C camera (Lumenera Corporation, Ottawa, Ontario, Canada) affixed to an American Optics BioStar microscope (Reichert, Inc., Depew, NY, USA).

\section{Verification of Adaptation End-Point}

Upon completion of the adaptation process, parent and HNO adapted cells were seeded $(100 \mu \mathrm{L})$ into 96 -well microtiter plates. (The adapted cells were seeded in media supplemented with $600 \mu \mathrm{M}$ DETA-NONONate; parent cells were seeded in media lacking DETA-NONOate.) Cells were grown for 24 hours, to $~ 70 \%$ confluency. The media was then removed and replaced with media containing either 0 or $600 \mu \mathrm{M}$ DETANONOate. Following an additional 72 hour incubation period, cell proliferation/viability was assessed using the MTT assay described above. 


\section{Normal Media Growth Assays}

Parent and HNO adapted cells were seeded into 96-well microtiter plates (100 $\mu \mathrm{L})$ such that a confluency of $\sim 30 \%$ would be reached 24 hours after seeding. HNO adapted cells were grown in media supplemented with $600 \mu \mathrm{M}$ DETA-NONOate. Parent cells were grown in media without DETA-NONOate. Cell viability was measured at 24, 48, and 72 hours after seeding using the MTT assay. At each time point, the media was removed, the MTT dye was added, and cell viability readings were obtained as described above. Each experiment was independently conducted a minimum of three times, and a minimum of four replicate wells were tested for each cell line at each time point. Data was normalized to the mean optical density value at the 24 hour time point, and values lying outside of two standard deviations were removed. Data was plotted as the mean normalized absorbance \pm standard error.

\section{Soft Agar Growth Assays}

A soft agar mixture consisting of 50\% melting point agarose (Sigma A-9539, Sigma-Aldrich Corp., St. Louis, MO, USA) and 50\% 2x MEM supplemented with 20\% fetal calf serum, $200 \mathrm{U} / \mathrm{mL}$ penicillin, $200 \mu \mathrm{g} / \mathrm{mL}$ streptomycin, $4 \mathrm{mM}$ L-glutamine, and $5 \mu \mathrm{g} / \mathrm{mL}$ Amphotericin B solution was prepared. This mixture was incubated at $42{ }^{\circ} \mathrm{C}$ for at least 30 minutes, after which time the agarose mixture $(100 \mu \mathrm{L})$ was loaded into a 96well microtiter plate $(100 \mu \mathrm{L})$. The agarose was then allowed to harden overnight at $4{ }^{\circ} \mathrm{C}$, after which time parent and HNO adapted cells $(100 \mu \mathrm{L})$ were added on top of the hardened agar. (HNO adapted cells were added in standard $1 \mathrm{X}$ growth media 
supplemented with $600 \mu \mathrm{M}$ DETA-NONOate; parent cells were added in standard $1 \mathrm{X}$ growth media lacking additional DETA-NONOate.) In order to allow the cells to attach to the soft agar, plates were incubated for 12 hours at $37^{\circ} \mathrm{C}$; after this time, the media above the agar was removed. The plates were incubated for another 24 or 72 hours, at which time MTT proliferation/viability assays were carried out. A $2 \mathrm{mg} / \mathrm{mL}$ MTT in PBS solution $(100 \mu \mathrm{L}$ ) was added to each well (on top of the agar), and the plates were incubated at $37^{\circ} \mathrm{C}$ for 5 hours. During this time, purple formazan crystals developed. Following the incubation period, the MTT solution was removed, and the remaining crystals were dissolved in DMSO $(100 \mu \mathrm{L})$, yielding a purple solution. The resulting supernatant in each well was then transferred to a new 96-well microtiter plate. This new plate was used to obtain the absorbance reading for each well as described above. Four replicate wells were tested for each cell line at each time point. Data was normalized to the mean optical density value at the 24 hour time point. Data was plotted as the mean normalized absorbance \pm standard deviation.

\section{$\mathrm{H}_{2} \mathrm{O}_{2}$ Exposure Growth Assays}

Cells were exposed to varying concentrations of hydrogen peroxide to determine if the adapted cells were resistant to high free-radical environments generated by oxygenbased free radicals. Parent and adapted cells were seeded $(100 \mu \mathrm{L})$ into 96-well microtiter plates in the appropriate media (parent cells in media without NO donor; HNO cells in media supplemented with $600 \mu \mathrm{M}$ DETA-NONOate) and incubated overnight, reaching approximately $70 \%$ confluency by the following day. Cells were treated with varying concentrations ( $0-1.78 \mathrm{mM})$ of hydrogen peroxide ( $30 \% \mathrm{w} / \mathrm{w}$ solution, Sigma H1009, 
Sigma-Aldrich Corp., St. Louis, MO, USA) and incubated at $37{ }^{\circ} \mathrm{C}$ for an additional 24 hours. MTT cell viability/proliferation assays were then performed, as described above. A minimum of four replicate wells were measured for each cell line at each concentration, and assays were repeated in triplicate. Data was normalized against the mean of the untreated control cells, and values lying outside of two standard deviations were removed. Data was plotted as the mean normalized absorbance \pm standard error.

\section{Data Analysis and Statistics}

Two-tailed Student's t-tests were run using Microsoft Excel 2007 in order to determine statistical significance between the growth rates of parent and HNO cells treated under identical conditions. $\mathrm{P}<0.05$ was considered statistically significant.

\section{Results}

\section{Cell Adaptation}

Five head and neck squamous cell carcinoma cell lines (SCC016, SCC040, SCC056, SCC114, and SCC116) were selected for this study. Three of the cell linesSCC016, SCC040, and SCC056 - originated from the tongue. SCC114 originated from the floor of mouth and SCC116 from the alveolar ridge. As with the previous studies carried out in our laboratory involving the adaptation of human lung and breast cancer cell lines [26,27], each of the five HNSCC cell lines was adapted to the nitric oxide donor DETA-NONOate. This donor was chosen based on its long half-life (approximately 24 hours at $37^{\circ} \mathrm{C}$ and $\mathrm{pH} 7.4$ ), free radical mode of delivery, and rate of delivery (donation of two moles of NO per one mole of donor) [26,29]. 
Prior to initiating the adaptation process, the five cell lines were exposed to varying doses $(0-600 \mu \mathrm{M})$ of DETA-NONOate for 72 hours to determine the minimum concentration of DETA-NONOate that was lethal to the cells. Each of the five cell lines exhibited similar results: cell death increased with increasing concentrations of NO donor [data not shown], and $600 \mu \mathrm{M}$ was the minimum concentration studied that was found to be completely lethal to the cells. Therefore, $600 \mu \mathrm{M}$ was chosen as the adaptation endpoint for each of the five HNSCC cell lines.

(We note that all concentrations referred to herein are the concentration of the NO donor added to the cells, and not the actual concentration of $\mathrm{NO}$ produced by the donor to which the cells are exposed. The latter will fluctuate based on the half-life of the donor, the age of the stock solution, and the incubation time used in the cell culture experiments. As such, expressing the concentration in terms of donor added enables for a more consistent measure in which to report the amount of $\mathrm{NO}$ applied to the cells.)

The adaptation process was carried out by gradually increasing the amount of DETA-NONOate added to the cell lines. Initially, cells were passaged with trypsinEDTA and introduced into media containing $50 \mu \mathrm{M}$ DETA-NONOate. Upon the next passaging event, an additional $25 \mu \mathrm{M}$ DETA-NONOate was added (for a total of $75 \mu \mathrm{M}$ DETA-NONOate). This process was continued for each cell line until the cells had been adapted to $600 \mu \mathrm{M}$ DETA-NONOate. A separate set of the original (i.e., "parent") cells, in which NO donor was not added, were maintained throughout the entire adaptation process.

Exposure to new levels of NO donor (i.e., each $25 \mu \mathrm{M}$ increase) typically resulted in an initially slower growth rate; however, all five of the cell lines studied herein 
recovered and eventually grew robustly at all concentrations studied. Figure 1 shows the adaptation curves for four of the HNSCC cell lines adapted herein. (SCC114 had an identical growth curve to SCC040 and therefore is not shown in the figure.) Each data point on the growth curve represents the addition of fresh DETA-NONOate solution to the growth media, either as a passaging event or as replenishment of the donor. Little difference was observed in the adaptation times for the five cell lines: SCC016 reached $600 \mu \mathrm{M}$ DETA-NONOate in approximately 85 days, SCC056 and SCC116 in 90 days, SCC040 and SCC114 in 95 days.

As mentioned above, initial reductions in cell growth were typically observed after the concentration of DETA-NONOate was increased. Extreme cell toxicity was observed only once - the initial attempt at introducing SCC116 to a concentration of 425 $\mu \mathrm{M}$ DETA-NONOate. In this case, the concentration of donor was reduced to $400 \mu \mathrm{M}$; within two days the cells had recovered and exhibited a normal growth rate. At this time the concentration was increased again to $425 \mu \mathrm{M}$, and the cells responded favorably to the increased concentration. The remainder of the adaptation proceeded as expected following the re-introduction of $425 \mu \mathrm{M}$ donor. Reductions in donor concentration were not needed at any point during the adaptation of the other four cell lines studied.

Each of the HNSCC HNO cell lines exhibited similar morphology to the untreated parent cells throughout the entire duration of the adaptation. Figure 2 compares the morphology of the parent cells versus the HNO cells adapted to $600 \mu \mathrm{M}$ DETANONOate. 


\section{Verification of Adaptation End-Point}

Upon adapting the HNO cells to $600 \mu \mathrm{M}$ DETA-NONOate, parent and HNO cells from each cell line were exposed to media containing either 0 or $600 \mu \mathrm{M}$ DETANONOate concentrations for 72 hours [data not shown]. In all five cell lines, the parent cells exhibited consistent growth in media lacking the DETA-NONOate, but were completely killed in media containing $600 \mu \mathrm{M}$ DETA-NONOate. In contrast, the HNO cells were able to grow robustly in media with or without the NO donor added.

\section{Normal Media Growth Curves}

Figure 3 shows the results of cell viability/proliferation of the parent cells in standard media and HNO cells in standard media supplemented with $600 \mu \mathrm{M}$ DETANONOate. Each of the HNO cell lines was found to grow faster than the corresponding parent cell line.

To verify that the enhanced growth of the HNO cell line was inherent in the cell line created, and not attributed merely to the DETA-NONOate serving as a growth stimulant, the HNO cell lines were grown in media in which the NO donor had been removed. No significant difference was observed between the growth curves of HNO cells grown in media with DETA-NONOate versus HNO cells grown in media without donor [data not shown] after 72 hours, confirming the HNO cells grow more aggressively than their corresponding parent cells.

\section{Soft Agar Growth Assays}


The ability of tumors to grow in low nutrient growth media, such as growth on soft agar, is used to measure a tumor's aggressiveness. Figure 4 shows growth curves on soft agar. Four of the five HNO cell lines were found to grow faster than their corresponding parent cell lines on soft agar; only SCC114 exhibited similar growth rates between parent and HNO cells.

\section{$\mathrm{H}_{2} \mathrm{O}_{2}$ Growth Assays}

Parent and HNO cells were grown in the presence of hydrogen peroxide to test if the cells could survive a high free radical environment generated by an oxygen-based donor. Comparatively high concentrations of $\mathrm{H}_{2} \mathrm{O}_{2}$ (above $55 \mu \mathrm{M}$ ) killed both parent and HNO cells upon 24 hour exposure [data not shown]. However, at lower concentrations $(0.4-14 \mu \mathrm{M})$, each of the five HNO cell lines exhibited a statistically significant $(\mathrm{P}<$ 0.05 ) higher cell viability than their corresponding parent cell line at one or more of the concentrations studied (Figure 5).

\section{Discussion}

The five parent cell lines chosen for the adaptation process are all squamous cell carcinomas in origin, and represent tumors arising from three different head and neck locations (tongue, floor of mouth, and alveolar ridge). All five parent cell lines were successfully adapted to high levels of the nitric oxide donor DETA-NONOate (Figure 1). As previously discussed in the adaptation of the human lung tumor [26] and breast tumor $[26,27]$ cell lines, DETA-NONOate was chosen as the NO donor because of its high level 
of free radical donation (two moles of NO per mole of DETA-NONOate) and relatively long half-life (approximately $24 \mathrm{hrs}$ at $37^{\circ} \mathrm{C}$ and $\mathrm{pH}$ 7.4). In general, the head and neck tumor cells were able to easily withstand the increased $25 \mu \mathrm{M}$ DETA-NONOate increments during the adaptation process. It was necessary to reduce the concentration due to significant toxicity in only one case (SCC116 at $425 \mu \mathrm{M}$ ), and in this case, the cells were able to recover quickly when the concentration was subsequently reduced.

As previously found for the adaptation of the lung and breast tumor cell lines [26,27], $600 \mu \mathrm{M}$ was a sufficient adaptation endpoint for each of the five head and neck cell lines. The parent cells were unable to survive at this concentration, but the HNO cells grew robustly, without a change in morphology (Figure 2).

The differences in the behavior of tumors growing in low and high free radical environments are clearly evident in this study. The HNO cells were all found to grow more aggressively than the parent cells in standard media (Figure 3) and on soft agar (Figure 4). These findings are consistent with the previously observed growth curves for the adapted lung and breast tumor cell lines [26,27]. Furthermore, the ability of the HNO cell lines to grow in media lacking DETA-NONOate demonstrates that short-term growth (up to 72 hours) of the $\mathrm{HNO}$ cells is not affected when the NO source is removed. Collectively these results indicate significant biological changes took place during the adaptation process, even though the parent and HNO cells are morphologically similar. While the nitrogen-based DETA-NONOate was chosen as the donor for the adaptation process, the HNO cells are also able to survive high levels of hydrogen peroxide (Figure 5), an oxygen-based free radical donor. This suggests the cells have protected themselves against free radicals in general, and not only against the nitrogen 
free radicals produced by DETA-NONOate or simply the inherent toxicity of the DETANONOate donor.

Our previously reported adaptation of the lung and breast tumor cell lines suggested the adaptation process was universal across adenocarcinomas [26,27], regardless of the origin of the tumor. Herein we have successfully utilized the same adaptation process for a series of squamous cell lines, suggesting the universality of this adaptation extends not only across like tumors arising from different sites, but also different tumor types. Furthermore, our adaptation process exposes the cells to periodic introduction of NO donor and subsequent decay. Given that free radicals are generated during radiation treatment, we believe our adaptation process mimics the long-term, cyclical free radical exposure many cancer patients receive during current radiation treatment protocols and suggests the need for hyperfractionation beyond what is currently being used.

The in vitro model system created herein can be used to study two distinct types of human head and neck tumors: those with slower propagation rates, growing in low-NO environments (represented by the parent cell lines) and those with faster propagation rates, which can grow aggressively in, and are resistant to, high NO environments (represented by the HNO cell lines). As evident from the results of the cell lines in this study, long-term exposure to NO can transform slower growing, less resistant tumor cells into faster growing, more resistant cells. However, the mechanism behind this transformation has not yet been determined. Understanding this parent-to-HNO transformation will be instrumental in determining the key factors that result in clinically aggressive tumors. 
In summary, this study, along with the previously reported work [26,27], confirms that both adenocarcinoma and squamous cell carcinoma cells can adapt to high concentrations of NO. These adapted cells exhibit biologically different properties from the parent cells, despite the identical morphologies found between the parent and HNO cells. Long-term exposure to increasing levels of NO results in fast-growing, resistant cells that mimic clinically aggressive tumors. While it is currently unknown why morphologically similar tumors vary in their aggressiveness, the model system developed herein could help to understand this clinical phenomenon by clarifying the parent-toHNO transformation process and identifying key biological differences between the parent and HNO cells. This new model system may also allow us to determine the mechanism which drives the in vivo progression from slower growing, NOS-expressing cells to faster growing, more aggressive cells. Furthermore, the parent/HNO model system could be used to predict therapeutic response to various treatment regiments, as well as potentially leading to new treatments designed to target the tumor microenvironment. To this end, the initial molecular and cellular characterization of the three parent/HNO human tongue squamous cell carcinoma cell line pairs developed herein (SCC016, SCC040, SCC056) are discussed in an accompanying manuscript [30].

\section{Acknowledgements}

This work was supported by a VA Merit Review Grant (J.A.R.) and a generous contribution from The Cherry Family Foundation. 


\section{References}

1. American Cancer Society I (2009) Cancer facts \& figures 2009. American Cancer Society, Inc. http://www.cancer.org/downloads/STT/500809web.pdf. Accessed March 26 2010

2. Campbell WJ, de la Torre J (2008) Head and neck cancer -- squamous cell carcinoma. Medscape. http://emedicine.medscape.com/article/1289986-overview. Accessed March 262010

3. Pryor WA (1997) Cigarette smoke radicals and the role of free radicals in chemical carcinogenicity. Environ Health Perspect 105 Suppl 4:875-882

4. Church DF, Pryor WA (1985) Free-radical chemistry of cigarette smoke and its toxicological implications. Environ Health Perspect 64:111-126

5. Culcasi M, Muller A, Mercier A, Clement JL, Payet O, Rockenbauer A, Marchand V, Pietri S (2006) Early specific free radical-related cytotoxicity of gas phase cigarette smoke and its paradoxical temporary inhibition by tar: An electron paramagnetic resonance study with the spin trap depmpo. Chem Biol Interact 164:215-231

6. Cerutti PA (1994) Oxy-radicals and cancer. Lancet 344:862-863

7. Valko M, Leibfritz D, Moncol J, Cronin MT, Mazur M, Telser J (2007) Free radicals and antioxidants in normal physiological functions and human disease. Int J Biochem Cell Biol 39:44-84

8. Valko M, Rhodes CJ, Moncol J, Izakovic M, Mazur M (2006) Free radicals, metals and antioxidants in oxidative stress-induced cancer. Chem Biol Interact 160:1-40 9. Moncada S, Palmer RM, Higgs EA (1991) Nitric oxide: Physiology, pathophysiology, and pharmacology. Pharmacol Rev 43:109-142 
10. Higashi Y, Noma K, Yoshizumi M, Kihara Y (2009) Endothelial function and oxidative stress in cardiovascular diseases. Circ J 73:411-418

11. Forstermann U (2008) Oxidative stress in vascular disease: Causes, defense mechanisms and potential therapies. Nat Clin Pract Cardiovasc Med 5:338-349

12. Mocellin S (2009) Nitric oxide: Cancer target or anticancer agent? Curr Cancer Drug Targets 9:214-236

13. Thomsen LL, Lawton FG, Knowles RG, Beesley JE, Riveros-Moreno V, Moncada S (1994) Nitric oxide synthase activity in human gynecological samples. Cancer Res $54: 1352-1354$

14. Thomsen LL, Miles DW, Happerfield L, Bobrow LG, Knowles RG, Moncada S (1995) Nitric oxide synthase in human breast cancer. Br J Cancer 72:41-44

15. Cobbs CS, Brenman JE, Aldape KD, Bredt DS, Israel MA (1994) Expression of nitric oxide synthase in human central nervous system tumors. Cancer Res 55:727-730 16. Ambs S, Merriam WG, Bennet WP, Felley-Bosco E, Ogunfusika MO, Oser SM, Klein S, Shields PG, Billiar TR, Harris CC (1998) Frequent nitric oxide synthase-2 expression in human colon adenomas: Implication for tumor angiogenesis and colon cancer progression. Cancer Res 58:334-341

17. Ambs S, Bennett WP, Merriam WG, Ogunfusika MO, Oser SM, Khan MA, Jones RT, Harris CC (1998) Vascular endothelial growth factor and nitric oxide synthase expression in human lung cancer and the relation to p53. Br J Cancer 78:233-239 18. Beevi SS, Rasheed MH, Geetha A (2007) Evidence of oxidative and nitrosative stress in patients with cervical squamous cell carcinoma. Clin Chim Acta 375:119-123 
19. Bentz BG, Haines III GK, Lingen MW, Pelzer HJ, Hanson DG, Radosevich JA (1999) Nitric oxide synthase type 3 is increased in squamous hyperplasia, dysplasia, and squamous cell carcinoma of the head and neck. Ann Otol Rhinol Laryngol 108:781-787 20. Bentz BG, Haines III GK, Hanson DG, Radosevich JA (1998) Endothelial constitutive nitric oxide synthase (ecnos) localization in normal and neoplastic salivary tissue. Head Neck 20:304-309

21. Chandra R, Haines III GK, Bentz BG, Shah P, Robinson AM, Radosevich JA (2001) Expression of nitric oxide synthase type 3 in reflux-induced esophageal lesions. Otolaryngol Head Neck Surg 124:442-447

22. Kizilay A, Kalcioglu MT, Ozugurlu F, Ozyurt H, Aladag I, Ozturan O, Akyol O (2007) Serum nitric oxide levels in patients with head and neck squamous cell carcinoma. Kulak Burun Bogaz Ihtis Derg 17:148-151

23. Jenkins DC, Charles IG, Thomsen LL, Moss DW, Holmes LS, Baylis SA, Rhodes P, Westmore K, Emson PC, Moncada S (1995) Roles of nitric oxide in tumor growth. Proc Natl Acad Sci USA 92:4392-4396

24. Thomas DD, Ridnour LA, Isenberg JS, Flores-Santana W, Switzer CH, Donzelli S, Hussain P, Vecoli C, Paolocci N, Ambs S, Colton CA, Harris CC, Roberts DD, Wink DA (2008) The chemical biology of nitric oxide: Implications in cellular signaling. Free Radic Biol Med 45:18-31

25. Wink DA, Vodovotz Y, Laval J, Laval F, Dewhirst MW, Mitchell JB (1998) The multifaceted roles of nitric oxide in cancer. Carcinogenesis 19:711-721 
26. Radosevich JA, Elseth KM, Vesper BJ, Tarjan G, Haines III GK (2009) Long-term adaptation of lung tumor cell lines with increasing concentrations of nitric oxide donor. The Open Lung Cancer Journal 2:35-44

27. Vesper BJ, Elseth KM, Tarjan G, Haines III GK, Radosevich JA (2010) Long-term adaptation of breast tumor cell lines to high concentrations of nitric oxide. Tumor Biol:In Press

28. Huang X, Gollin SM, Raja S, Godfrey TE (2002) High-resolution mapping of the $11 \mathrm{q} 13$ amplicon and identification of a gene, taos1, that is amplified and overexpressed in oral cancer cells. Proc Natl Acad Sci USA 99:11369-11374

29. Bentz BG, Hammer ND, Milash B, Klein S, Burnett DM, Radosevich JA, Haines III GK (2007) The kinetics and redox state of nitric oxide determine the biological consequences in lung adenocarcinoma. Tumor Biol 28:301-311

30. Tarjan G, Haines III GK, Vesper BJ, Xue J, Altman MB, Yarmolyuk Y, Elseth KM, Roeske JC, Aydogan B, Radosevich JA (2010) Part ii. Initial molecular and cellular characterization of high nitric oxide-adapted human tongue squamous cell carcinoma cell lines. Tumor Biol:Submitted in conjunction with current manuscript 


\section{Figure Legends}

Figure 1. Adaptation curves of the head and neck cancer cell lines (Top: SCC016, SCC040; Bottom: SCC056, SCC116). SCC114 had an identical adaptation curve to SCC040, and is therefore not shown. Each data point represents the addition of fresh DETA-NONOate, either as a passaging event or a replenishment of media

Figure 2. Images depicting cellular morphology of parent (left) and HNO (right) head and neck cell lines (Top-to-bottom: SCC016, SCC040, SCC056, SCC114, SCC116). Images collected at $100 \mathrm{x}$ magnification

Figure 3. MTT viability/proliferation curves of parent and HNO head and neck tumor cells in standard growth media. The media of the HNO cells was supplemented with 600 $\mu \mathrm{M}$ DETA-NONOate. Data is shown as the mean normalized absorbance \pm standard error $(n=3 ; * \mathrm{P}<0.05$ versus parent cells, $* * \mathrm{P}<0.01$ versus parent cells $)$

Figure 4. MTT viability/proliferation curves of parent and HNO head and neck tumor cells grown on soft agar. The media of the HNO cells was supplemented with $600 \mu \mathrm{M}$ DETA-NONOate. Data is shown as the mean normalized absorbance \pm standard deviation $(n=1)$

Figure 5. MTT viability/proliferation curves of parent and HNO head and neck tumor cells exposed to varying concentrations of hydrogen peroxide for 24 hours. The media of the HNO cells was supplemented with $600 \mu \mathrm{M}$ DETA-NONOate. Data is shown as the mean normalized absorbance \pm standard error $\left(n=3 ; * \mathrm{P}<0.05\right.$ versus parent cells, ${ }^{* *} \mathrm{P}<$ 0.01 versus parent cells) 
Figure 1
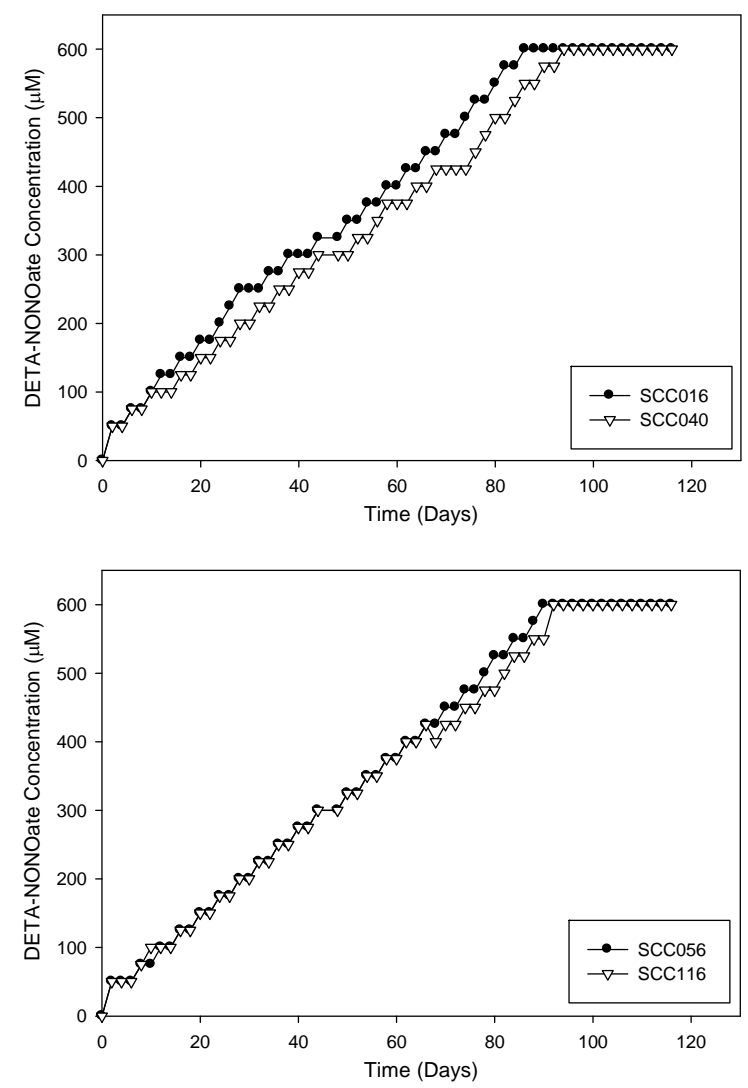
Figure 2

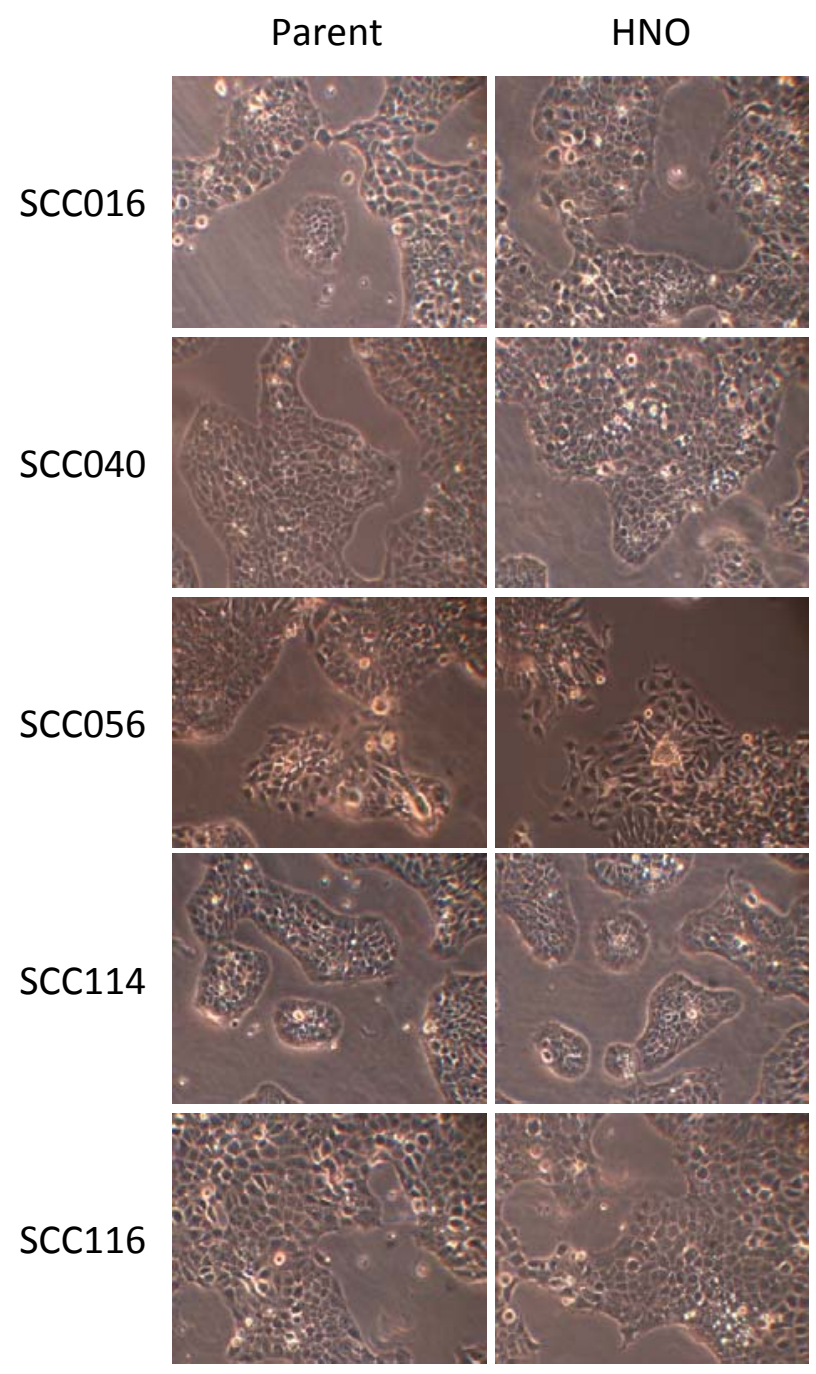


Figure 3
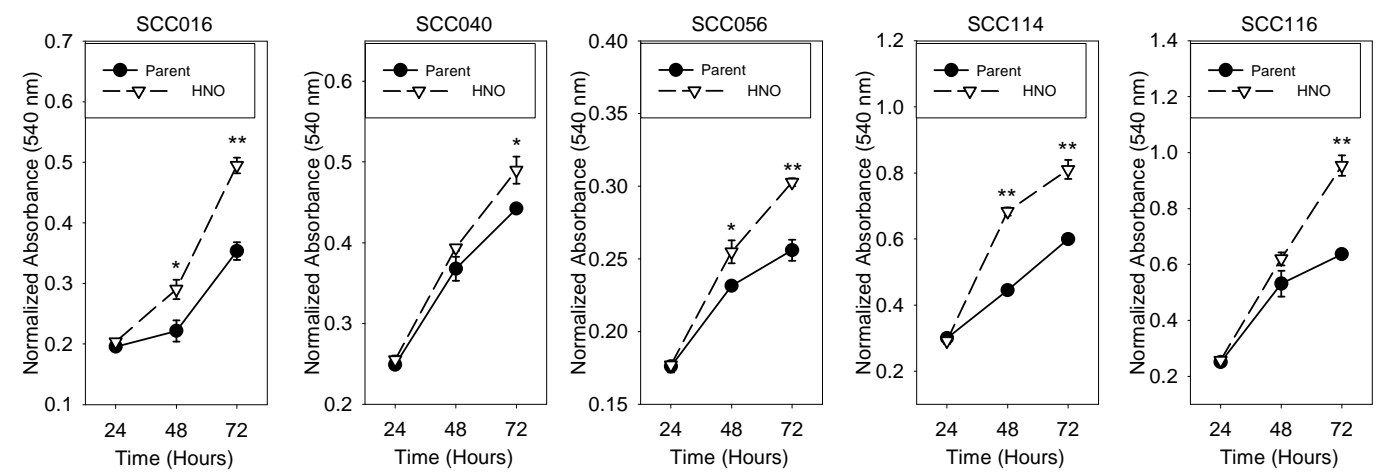
Figure 4
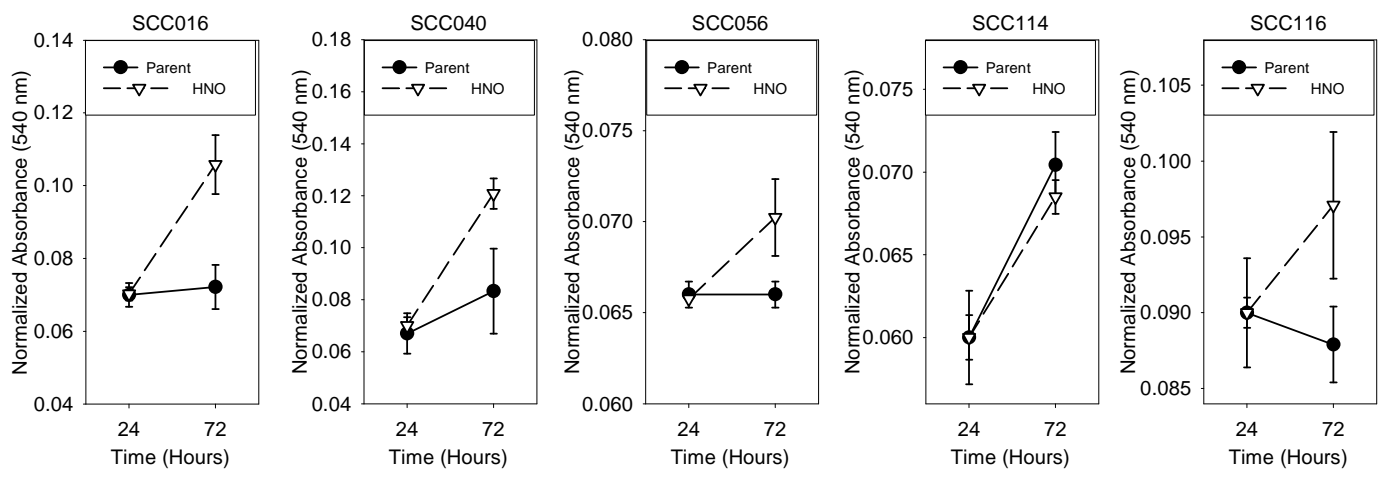
Figure 5
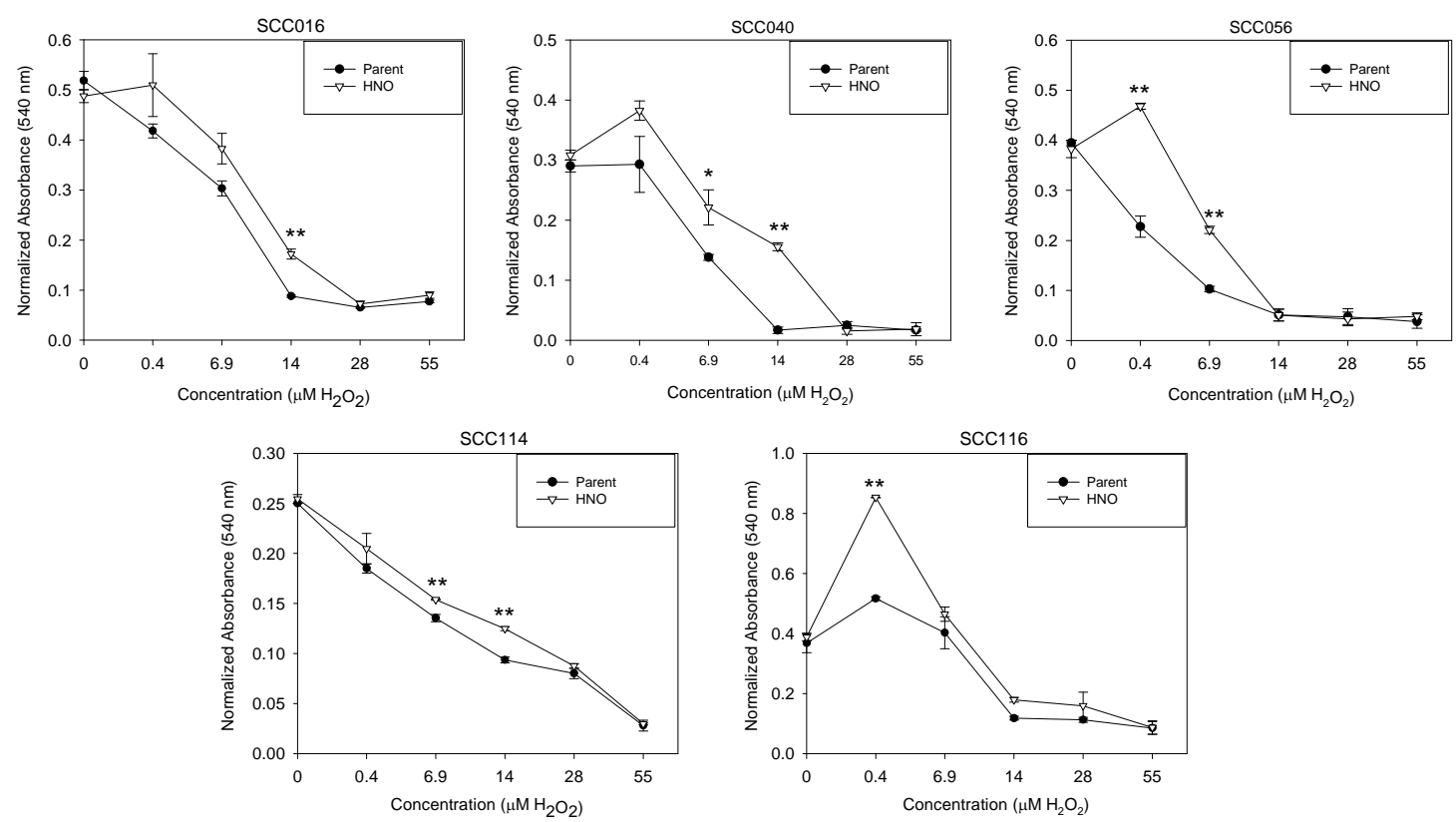